\title{
Mesencephalic Type 1 Astrocytes Rescue Dopaminergic Neurons from Death Induced by Serum Deprivation
}

\author{
Takao Takeshima, Jane M. Johnston, and John W. Commissiong \\ Neural Transplantation Unit, LMCN-NINDS-NIH, Bethesda, Maryland 20892
}

We have established a primary neuronal culture of the embryonic day 14 rat, ventral mesencephalic region, centered on the A8, A9, and $A 10$ dopaminergic nuclei $\left(\approx 1.0 \mathrm{~mm}^{3}\right.$ of tissue). At $16 \mathrm{hr}$ after plating on a substrate of poly-D-lysine, in a serum-free or serum-supplemented growth medium, using a microisland culturing method, $95 \%$ of the cells stained positive for neuron-specific enolase, $20 \%$ for tyrosine hydroxylase, and $<5 \%$ for vimentin. When the growth medium was supplemented with $10 \%$ fetal calf serum, the percentage of tyrosine hydroxylase-positive neurons increased significantly $(p<0.05)$ at the 7 th and 10 th days in culture, compared with the percentage present at $16 \mathrm{hr}$ after plating. When cultured in a serum-free growth medium, the percentage of tyrosine hydroxylase-positive neurons decreased to $<5 \%$ and to $0 \%$ by the 5 th and 7 th days, respectively, while the percentage of GABA-IR neurons increased. The addition of serum to the serum-free culture rescued dopaminergic neurons from death induced by serum deprivation. The effect of serum was dependent both on the time of addition after plating, and on the percentage added. When the cells were plated in a serum-free medium, on a confluent, type 1 astrocyte monolayer, prepared from the ventral mesencephalon of the embryonic day 16 rat, the survival of dopaminergic neurons increased significantly ( $p$ $<0.01$ ) at DIV5, versus survival after plating on poly-D-lysine. Conditioned medium prepared from the same mesencephalic type 1 astrocyte monolayer also rescued dopaminergic neurons from death. The rescue mediated by the astrocyte monolayer or the conditioned medium was not inhibited by the mitotic inhibitor cytosine arabino furanoside $(1.0 \mu \mathrm{M})$. Type 1 astrocyte monolayers and conditioned media prepared from the striatum and cerebral cortex of the embryonic day 16 rat had weaker trophic effects than those mediated by mesencephalic glia. We conclude that serum deprivation causes the selective death of dopaminergic neurons in a primary culture of the rat E14 ventral mesencephalon. Type 1 astrocytes or the conditioned medium from type 1 astrocytes can rescue dopaminergic neurons from death induced by serum deprivation. The dissection technique used, which yields a high percentage $(20 \%)$ of tyrosine hydroxylase-positive neurons, the low percentage of glia in the initial culture ( $<5.0 \%$ were vimentin positive), the use of a mi-

\footnotetext{
Received June 11, 1993; revised Jan. 13, 1994; accepted Jan. 27, 1994.

This work was supported by DIR-NINDS-NIH.

Correspondence should be addressed to J. W. Commissiong, Neural Transplantation Unit, LMCN-NINDS-NIH, Building 10/5 N214, 9000 Rockville Pike, Bethesda, MD 20892.

Copyright (C) 1994 Society for Neuroscience $0270-6474 / 94 / 144769-11 \$ 05.00 / 0$
}

croisland culturing method, and the use of serum deprivation as the stimulus to induce cell death will be of value in future experiments designed to isolate dopaminergic neurotrophic factors from type 1 astrocytes.

[Key words: tissue culture, neurotrophic factor, microisland cultures, serum-free growth medium, immunocytochemistry, conditioned medium]

It is likely that each neuronal phenotype in the adult brain may require a phenotype-specific, neurotrophic factor for its normal, functional maintenance. Loss of, or a decrease in the concentration of a particular neurotrophic factor may therefore cause the selective degeneration of a particular neuronal phenotype, and may lead to unique clinical signs, as in Parkinson's disease and Alzheimer's disease (Appel, 1981; Barde, 1989; Oppenheim, 1989; Hefti et al., 1990). Therefore, a considerable effort is being devoted to the identification of phenotype-specific, neurotrophic factors. The search for dopaminergic-specific neurotrophic factors is of particular importance, because of the relevance of dopaminergic neurons to the etiology of Parkinson's disease. Brain-derived neurotrophic factor (BDNF), a member of the neurotrophin family, has been shown to rescue dopaminergic (Hyman et al., 1991; Knüsel et al., 1991) and cholinergic (Alderson et al., 1990; Nonomura and Hatanaka, 1992) neurons from natural cell death, as well as axotomy- and neurotoxin-induced death (Knüsel et al., 1992; Spina et al., 1992). Recently, Lin et al. (1993) have isolated a novel glia cell linederived neurotrophic factor (GDNF) from B49 glia, and demonstrated its effectiveness at the picomolar concentration, in rescuing dopaminergic neurons from neurotoxin-induced death. Epidermal growth factor (EGF), basic fibroblast growth factor (bFGF), and platelet-derived growth factor (PDGF), known mitogens for glia (Besnard et al., 1987; Diamond et al., 1989; Engele and Bohn, 1991; Ferrari et al., 1991; Basilico and Moscatelli, 1992), also exert neurotrophic effects on dopaminergic neurons (Ferrari et al., 1989; Casper et al., 1991; Hadjiconstantinou et al., 1991; Otto et al., 1991; Nikkhah et al., 1993). Mesencephalic, type 1 astrocytes produce factors that exert direct effects on the development and survival of dopaminergic neurons in culture (Engele et al., 1991; O’Malley et al., 1991, 1992; Shimoda et al., 1992; Takeshima et al., 1992; Walsh et al., 1992). In the present experiments, we have found that serum deprivation caused a specific, precipitous decline in the percentage of tyrosine hydroxylase-positive $\left(\mathrm{TH}^{+}\right)$neurons in culture, while the percentage of GABA-IR neurons increased under the same conditions. This obscrvation provided the basis for testing the ability of factors derived from type 1 astrocytes to reverse the toxic effects caused by serum deprivation. We have used a microisland culturing technique, combined with a dis- 
section procedure (Shimoda et al., 1992), which yields, at plating, a high $(20 \%)$ percentage of $\mathrm{TH}^{+}$neurons, and $<5 \%$ glia. We provide a detailed account of the effects of type 1 astrocytes, conditioned media, and serum in the regulation of the survival of dopaminergic neurons in a primary culture.

\section{Materials and Methods}

Culture medium and chemicals. The serum-free medium used consisted of equal volumes of Dulbecco's modified Eagle's medium (DMEM) and Ham's F-12 (GIBCO, Grand Island, NY; 320-1320AJ), including 4.0 mM glutamine (GIBCO, 320-5039AF), $1.0 \mathrm{mg} / \mathrm{ml}$ bovine albumin fraction V (Sigma Chemical Co., St. Louis, MO; A-4161), $0.1 \mathrm{mg} / \mathrm{ml}$ apotransferrin (Sigma, T-7786), $5 \mu \mathrm{g} / \mathrm{ml}$ insulin (Sigma, I-1882), $30 \mathrm{~nm}$ L-thyroxine (Sigma, T-0397), 20 nM progesterone (Sigma, P-6149), 30 nM sodium selenite (Sigma, S-5261), $100 \mathrm{U} / \mathrm{ml}$ penicillin and $100 \mu \mathrm{g} /$ $\mathrm{ml}$ streptomycin (GIBCO, P-100-1-91). In the experiments involving serum-supplemented medium for the primary neuronal cultures, fetal calf serum (FCS; Biofluids Laboratories, Rockville, MD) made up 0$15 \%$ of the growth medium. Serum-supplemented medium for the astrocyte cultures consisted of equal volumes of DMEM and Ham's F-12, plus $6.0 \mathrm{~mm}$ glutamine, $10 \% \mathrm{FCS}, 100 \mathrm{U} / \mathrm{ml}$ penicillin, and $100 \mu \mathrm{g} / \mathrm{ml}$ streptomycin. Serum-free medium for astrocyte cultures consisted of equal volume of DMEM and Ham's F-12, plus $6 \mathrm{~mm}$ glutamine, $30 \mathrm{~nm}$ sodium selenite, $100 \mathrm{U} / \mathrm{ml}$ penicillin and $100 \mu \mathrm{g} / \mathrm{ml}$ streptomycin. Cytosine $\beta$-D-arabino furanoside (AraC; Sigma, C1768) was dissolved in Dulbecco's phosphate-buffered saline (DPBS) at a concentration of 100 $\mu \mathrm{M}$, aliquoted in $100 \mu \mathrm{l}$ volumes, and stored in the dark at $-70^{\circ} \mathrm{C}$ until used.

Mesencephalic dopaminergic neurons in serum-free culture medium. Timed-pregnant Sprague-Dawley rats were purchased from Taconic (Germantown, NY). The primary culture of mesencephalic cells was prepared as described previously (Shimoda et al., 1992), except that the dissected tissue was collected and pooled in oxygenated, cold, serumfree medium. In brief, pregnant rats were exposed to $\mathrm{CO}_{2}$ on the 14 th gestational day (E14), and following a laparotomy, the E14 fetuses were collected in cold DPBS, pH 7.4, without $\mathrm{Ca}^{2+}$ or $\mathrm{Mg}^{2+}$. Subsequently, the brain was removed intact, and the brainstem isolated. Dissections were done in cold DPBS without $\mathrm{Ca}^{2+}$ or $\mathrm{Mg}^{2+}$. A cut was made between the diencephalon and mesencephalon, and the tectum slit medially, and spread out laterally. The ventral, medial $1.0 \mathrm{~mm}^{3}$ block of tissue comprising the mesencephalic dopaminergic region (Shimoda et al., 1992) (centered on the A8, A9, and A10 dopaminergic nuclei) was isolated. Dissected tissue blocks were pooled in oxygenated, cold $\left(4^{\circ} \mathrm{C}\right)$ serumfree medium. The tissue was triturated using a $1000 \mu$ l pipette with a blue tip, and then a $21 \mathrm{G}$ needle fitted to a $1.0 \mathrm{ml}$ plastic syringe. Special care was taken to prevent the cells from touching the rubber at the tip of the plunger, and not to create bubbles in the cell suspension. The dispersed cells were transferred to $1.5 \mathrm{ml}$ Eppendorf tubes $(1.0 \mathrm{ml} /$ tube) and spun at $1,500 \mathrm{rpm}$ for $5 \mathrm{~min}$, the medium was carefully removed, and the cells were resuspended in fresh, serum-free medium and counted using a hemocytometer. Cell viability was evaluated using a two-color fluorescence cell viability assay kit (Live/Dcad Viability/Cytotoxicity Assay Kits, Molecular Probes, Inc., Eugene, OR). This method of evaluating cell viability gives two positive results (red for dead cells and green for living cells), and is more accurate and reliable than the trypan blue method. Cell viability just before plating was $>90 \%$. All procedures, from laparotomy to plating were done within $2 \mathrm{hr}$. In a typical experiment, three litters ( $25-40$ fetuses) were used, yielding $2.5-4.0 \times$ $10^{6}$ cells.

Microisland culture. The cells were resuspended at a density of $5.0 \times$ $10^{\mathrm{s}} / \mathrm{ml}$. A $25 \mu \mathrm{l}$ droplet of the suspension $\left(1.25 \times 10^{4}\right.$ cells $)$ was plated on eight-well chamber slides, coated with poly-D-lysine. The droplet occupied an area of $\approx 6.2 \mathrm{~mm}^{2}$, for a final density of $2.0 \times 10^{5} / \mathrm{cm}^{2}$. The covered chambers were incubated at $37^{\circ} \mathrm{C}$, in $5 \% \mathrm{CO}_{2}$ at $100 \%$ humidity, for $4 \mathrm{hr}$ to allow the cells to attach to the coated surface. Subsequently, $375 \mu \mathrm{l}$ of serum-frce mcdium was added to each well. Fifty percent of medium was changed every $2 \mathrm{~d}$. In the present serumfree, microisland cultures, the optimal plating density was $2.0 \times 10^{5} /$ $\mathrm{cm}^{2}$. A plating density of $>5.0 \times 10^{5} / \mathrm{cm}^{2}$, or $<7.5 \times 10^{4} / \mathrm{cm}^{2}$ resulted in poor neuronal survival and development. In this study, the plating density used was $2.0 \times 10^{5} / \mathrm{cm}^{2}$, unless stated otherwise.

Type $l$ astrocyte cultures and conditioned medium. Glial cultures were prepared from the ventral mesencephalon, striatum, and cerebral cortex of the E16 rat using the method of McCarthy and De Vellis (1980). The cells were dispersed mechanically and resuspended in a medium supplemented with $15 \%$ serum. The ventral mesencephalic cells were plated initially at a density of $2.0 \times 10^{4} / \mathrm{cm}^{2}$, and the striatal and cerebral cortical cells at $4.0 \times 10^{4} / \mathrm{cm}^{2}$, on uncoated, plastic, $75 \mathrm{~cm}^{2}$ Falcon flasks (T-75: Becton Dickinson \& Co., UK). The medium containing the unattached neurons was replaced on DIV2. On DIV5, $50 \%$ of the medium was changed. At DIV9, the flasks were shaken for $15-18 \mathrm{hr}$, at $250 \mathrm{rpm}$, and the cells washed $(2 \times 8 \mathrm{ml})$ with culture medium. The cells were detached using trypsin $(0.05 \%)$, washed with $\mathrm{Na}_{4}$ EDTA $(0.53$ $\mathrm{mm}$ ), and resuspended in medium supplemented with $15 \%$ serum, and plated at the same density of $1.5 \times 10^{4} / \mathrm{cm}^{2}$ using new T-75 Falcon flasks. In these replated cultures, $100 \%$ and $50 \%$ of the culture medium was changed at DIV 1 and DIV4, respectively. The replated cells became confluent at DIV7. Serum-free growth medium was then used in all subsequent medium changes. At DIV7, 50\% of the medium was replaced. At DIV10, 100\% of the medium was replaced. At DIV11, 100\% of the medium was again replaced. This systematic method of changing the medium is essential to exclude the possibility of contamination of the serum-free medium with serum. Conditioned medium for testing was collected at DIV 16 after replating, equivalent to the fifth day after the last change of medium. The protein content of the conditioned medium was determined using a modification of the method of Lowry (Peterson, 1977), designed to avoid interference by phenol red. Conditioned media obtained from different astrocyte preparations were standardized on the basis of protein content. At the time of the passage, sister cultures were plated on eight-well chamber slides to determine the glial phenotypes and to prepare astrocyte monolayers for use in other experiments. The schedule of medium exchange in the sister cultures was identical to that described above for the bulk culture of astrocytes. In order to test for the possible contamination of the astrocyte cultures by microglia, at replating at DIV9, some of the astrocytes were cultured in chamber slides at a density of $2.5 \times 10^{4} / \mathrm{cm}^{2}$, and stained with anti-OX-42 $5 \mathrm{~d}$ later. No positive cells were found. A positive control was prepared by culturing E16 cortical cells directly in chamber slides, using a growth medium containing $10 \%$ serum. Fifty percent of the medium was changed every other day. Staining with anti-OX-42 was done at DIV10, and one or two microglia per field were found (see Fig. $8 A$ ). Similar cultures were done using E16 striatal tissue and ventral mesencephalic, and no OX-42-positive cells were found.

Immunocytochemistry. The antibodies used in the study, at the appropriate dilutions, are listed in Table 1 . Immunostaining to visualize tyrosine hydroxylase (TH) was done according to the method of Schachner (1983), with minor modifications (Poltorak et al., 1990; Shimoda et al., 1992). The cultures were washed $(2 \times 250 \mu l)$ with cold DPBS, fixed with 4\% paraformaldehyde in PBS for $10 \mathrm{~min}$, permeabilized using $1 \% \mathrm{CH}_{3} \mathrm{COOH}, 95 \% \mathrm{EtOH}$ at $-20^{\circ} \mathrm{C}$, for $5 \mathrm{~min}$, and then washed $(3$ $\times 250 \mu$ l) with PBS. Nonspecific binding was blocked with $1 \%$ bovine serum albumin in PBS (BSA-PBS) for $15 \mathrm{~min}$. Anti-TH antibody (50 $\mu$ ) was applied to each well, and the chamber slides incubated in a dark humid box at room temperature for $30 \mathrm{~min}$. After washing $(2 \times 250$ $\mu \mathrm{l})$ with BSA-PBS, anti-mouse IgG-FITC $(50 \mu \mathrm{l})$ was applied, and the slides incubated for a further $30 \mathrm{~min}$. After washing with BSA-PBS (2 $\times 250 \mu \mathrm{l})$ plus DPBS $(1 \times 250 \mu \mathrm{l})$, excess fluid was aspirated, the chamber walls removed, and 1.5 drops of Vectashield mounting medium was applied, followed by a cover glass, which was sealed with nail polish. Control staining was done using mouse serum at the same dilution as the anti-TH antibody. For GABA and NSE, essentially the same procedure used to visualize $\mathrm{TH}$ was repeated, except that the secondary antibody was anti-rabbit IgG-FITC, and rabbit serum was used for the control staining. For vimentin, GFAP and OX-42, after a single wash with cold DPBS $(250 \mu \mathrm{l})$, fixation and permeabilization were done in a single step, using $5 \% \mathrm{CH}_{3} \mathrm{COOH}, 95 \% \mathrm{EtOH}$, at $-20^{\circ} \mathrm{C}$ for $20 \mathrm{~min}$. The subsequent procedures were the same as those used to visualize TH. For A2B5 the cultures were washed with cold DPBS (2 $\times 250 \mu \mathrm{l})$, and blocked with $1 \%$ BSA-PBS for $10 \mathrm{~min}$. The anti-A2B5 antibody $(50 \mu 1)$ was applied to each well, and incubated for $30 \mathrm{~min}$. After washing with DPBS $(2 \times 250 \mu \mathrm{l})$, the secondary antibody, antiIgM-FITC, was applied for $30 \mathrm{~min}$. The cells were then washed with DPBS $(2 \times 250 \mu \mathrm{l})$, and fixed with $5 \% \mathrm{CH}_{3} \mathrm{COOH}, 95 \% \mathrm{EtOH}$, at $-20^{\circ} \mathrm{C}$ for 20 min. After a final washing with cold DPBS $(2 \times 250 \mu \mathrm{l})$, they were mounted as described above. For NeuroTag staining, used to estimate the total number of neurons on some cultures (see Figs. 4-8), the cells were washed with DPBS $(2 \times 250 \mu \mathrm{l})$, fixed with $4 \%$ parafor- 
Table 1. Antibodies used in the present study

\begin{tabular}{|c|c|c|c|c|c|}
\hline Antibodies & Abbreviation & Marker & Properties & Dilution & Source \\
\hline Anti-tyrosine hydroxylase & TH & Dopaminergic neuron & Mouse IgG2a, Mab & $0.8 \mu \mathrm{g} / \mathrm{ml}$ & Boehringer-Mannheim \\
\hline Anti- $\gamma$-aminobutyric acid & GABA & GABA-IR cell & Rabbit IgG, AS & $3000 \times$ & Sigma Immunochemicals \\
\hline Anti-neuron-specific enolase & NSE & $\begin{array}{l}\text { Neuron } \\
\text { Neuron }\end{array}$ & Rabbit IgG, AS & $3000 x$ & Polysciences, Inc \\
\hline $\begin{array}{l}\text { Fluorescein (rhodamine)-conjugated } \\
\text { tetanus toxin } \mathrm{C} \text { fragment }\end{array}$ & NeuroTag & Glia, glioblast, & Recombinant & $5 \mu \mathrm{g} / \mathrm{ml}$ & Boehringer-Mannheim \\
\hline Anti-vimentin (clone V9) & Vim & neuroblast & Mouse IgG1, Mab & $140 \mu \mathrm{g} / \mathrm{ml}$ & Boehringer-Mannheim \\
\hline $\begin{array}{l}\text { Anti-glial fibrillary } \\
\text { acidic protein }\end{array}$ & GFAP & Astrocyte & Mouse IgG1, Mab & $100 \mathrm{ng} / \mathrm{ml}$ & Boehringer-Mannheim \\
\hline Anti-OX -42 & OX -42 & Microglia & Mouse IgG2a, Mab & $100 \times$ & Serotec \\
\hline Anti-A2B5 (clone 105) & A2B5 & $\mathrm{O}-2 \mathrm{~A}$ lineage cells & Mouse IgM, Mab & $10 \mu \mathrm{g} / \mathrm{ml}$ & Boehringer-Mannheim \\
\hline $\begin{array}{l}\text { FITC-conjugated } \\
\text { anti-mouse IgG }\end{array}$ & - & Mouse IgG & Rabbit & $8.0 \mu \mathrm{g} / \mathrm{ml}$ & Dakopatts \\
\hline $\begin{array}{l}\text { Texas red conjugated } \\
\text { anti-mouse IgG }\end{array}$ & - & Mouse IgG & Goat & $30 \mu \mathrm{g} / \mathrm{ml}$ & Vector Lab \\
\hline $\begin{array}{r}\text { FITC-conjugated } \\
\text { anti-rabbit IgG }\end{array}$ & - & Rabbit IgG & Goat & $30 \mu \mathrm{g} / \mathrm{ml}$ & Vector Lab \\
\hline $\begin{array}{l}\text { FITC-conjugated } \\
\text { anti-mouse IgM }\end{array}$ & - & Mouse IgM & Goat & $20 \mu \mathrm{g} / \mathrm{ml}$ & Vector Lab \\
\hline
\end{tabular}

FITC, fluorescein isothiocyanate; AS, antisera; Mab, monoclonal antibody.

maldehyde for $10 \mathrm{~min}$, and exposed to NeuroTag $(50 \mu \mathrm{l})$ for $90 \mathrm{~min}$. They were then washed $(3 \times 250 \mu \mathrm{l})$ and mounted.

Evaluation of $\mathrm{TH}^{+}$and GABA-IR neuronal survival. A Nikon Microphot-FXA microscope, equipped with the appropriate filters for fluorescence microscopy, was used to visualize the cells. $\mathrm{The}^{\mathrm{TH}^{+}, \mathrm{GABA}^{-}}$ IR, NSE ${ }^{+}$, and NeuroTag ${ }^{+}$neurons were counted in a $0.4 \mathrm{~mm}^{2}$ area ( $2.6 \%$ of the plated area) using an eye grid. For the microisland cultures four fields were counted, and the mean values used to estimate the cell number per $\mathrm{cm}^{2}$. For TH and GABA, more than four wells were stained, and for NSE and NeuroTag, more than two wells were stained. The percentage of $\mathrm{TH}^{+}$or GABA-IR neurons was calculated as (number of $\mathrm{TH}^{+}$[GABA-IR] neurons/number of $\mathrm{NSE}^{+}$neurons) $\times 100$. When the cells were plated on an astrocyte monolayer, covering the entire area of the well, after staining, a $10 \times$ objective was used to count all of the $\mathrm{TH}^{+}$neurons in the entire area of the well. The above procedure was followed, in order to avoid bias in selecting fields for counting, since the cells were usually distributed unevenly.

Statistics. The data were analyzed using a one-way analysis of variance (ANOVA), followed by post hoc testing using the Student-NewmanKeuls test for comparison of multiple pairs of data, as appropriate. In cases of failure of the normality test, or equal variance test, KruskalWallis ANOVA (nonparametric tests) were used.

\section{Results}

Characterization of serum-free cultures and the effect of serum deprivation

At $4 \mathrm{hr}$ after plating, the earliest time at which it was possible to immunostain without causing cell detachment, $95 \%$ of the cells were $\mathrm{NSE}^{+}$(or NeuroTag ${ }^{+}$), 17-20\% $\mathrm{TH}^{+}, 5 \%$ vimentin positive, and $<1 \%$ A2B 5 positive. The percentages of GABAIR neurons in the culture were $0 \%$ and $10 \%$ at $4 \mathrm{hr}$ and $16 \mathrm{hr}$, respectively. A profile of the culture is illustrated in Figure 1, at $16 \mathrm{hr}(A, C, E)$ and at $\operatorname{DIV} 7(B, D, F)$. When grown on a poly-D-lysine substrate, in a growth medium supplemented with $10 \%$ serum, and in the absence of the mitotic inhibitor $\mathrm{AraC}$, the percentage of $\mathrm{TH}^{+}$neurons was increased significantly $(p<$ 0.05 ) at DIV7 and DIV10 (Fig. 2A), compared with cultures assayed at $16 \mathrm{hr}$ after plating. However, when grown in serumfree medium, the percentage of $\mathrm{TH}^{+}$neurons decreased significantly ( $p<0.001)$ at DIV4, DIV7, and DIV10 (Fig. 2A), com- pared with cultures grown in a serum-supplemented medium. In fact, $<1.0 \%$ of the $\mathrm{TH}^{+}$neurons survived after DIV7, in serum-free medium (Fig. $2 A$ ). In contrast, the percentage of GABA-IR neurons increased progressively, in both the serumfree and serum-supplemented media (Fig. 2B), but achieved statistical significance only in the serum-free cultures. The markcd differences in neuronal survival in general, and of $\mathrm{TH}^{+}$neurons in particular, in serum-free and serum-supplemented media are illustrated at DIV3, in Figure 3. The marked differences in the survival of GABA-IR and $\mathrm{TH}^{+}$neurons suggest that phenotypic specificity is a significant factor under our experimental conditions.

The inhibitory effect of the serum-free medium on glial proliferation was equally pronounced. GFAP was not expressed, even at DIV10, when the cells were grown in a serum-free medium. The expression of vimentin and A2B5 was also reduced. However, the expression of GFAP in serum-supplemented medium was marked even at DIV3, and pronounced at DIV10. The data summarized in Table 2 illustrate the expression of vimentin, GFAP, and A2B5 in serum-free and serum-supplemented media, at DIV4 and at DIV10. The severe toxic effect of serum deprivation (see Fig. $2 A$ ), and the parallel relationship between glial proliferation and the percentage of $\mathrm{TH}^{+}$neurons in the culture are also demonstrated in Table 2. The addition of serum to the serum-free culture after $48 \mathrm{hr}$ failed to rescue the $\mathrm{TH}^{+}$neurons from death (Fig. 4), when assessed at DIV5 and DIV 10.

\section{Mesencephalic type I astrocytes rescuc dopaminergic neurons from neuronal death induced by serum deprivation}

After a single passage, type 1 astrocytes that were replated on chamber slides coated with poly-D-lysine became confluent after DIV7. At this time, $>95 \%$ of the cells were GFAP positive, $<1 \%$ were A2B 5 positive, and microglia were absent (see Fig. $8 C$ ). After switching to a serum-free medium, about one-third of the cells stopped expressing, or reduced their expression of 

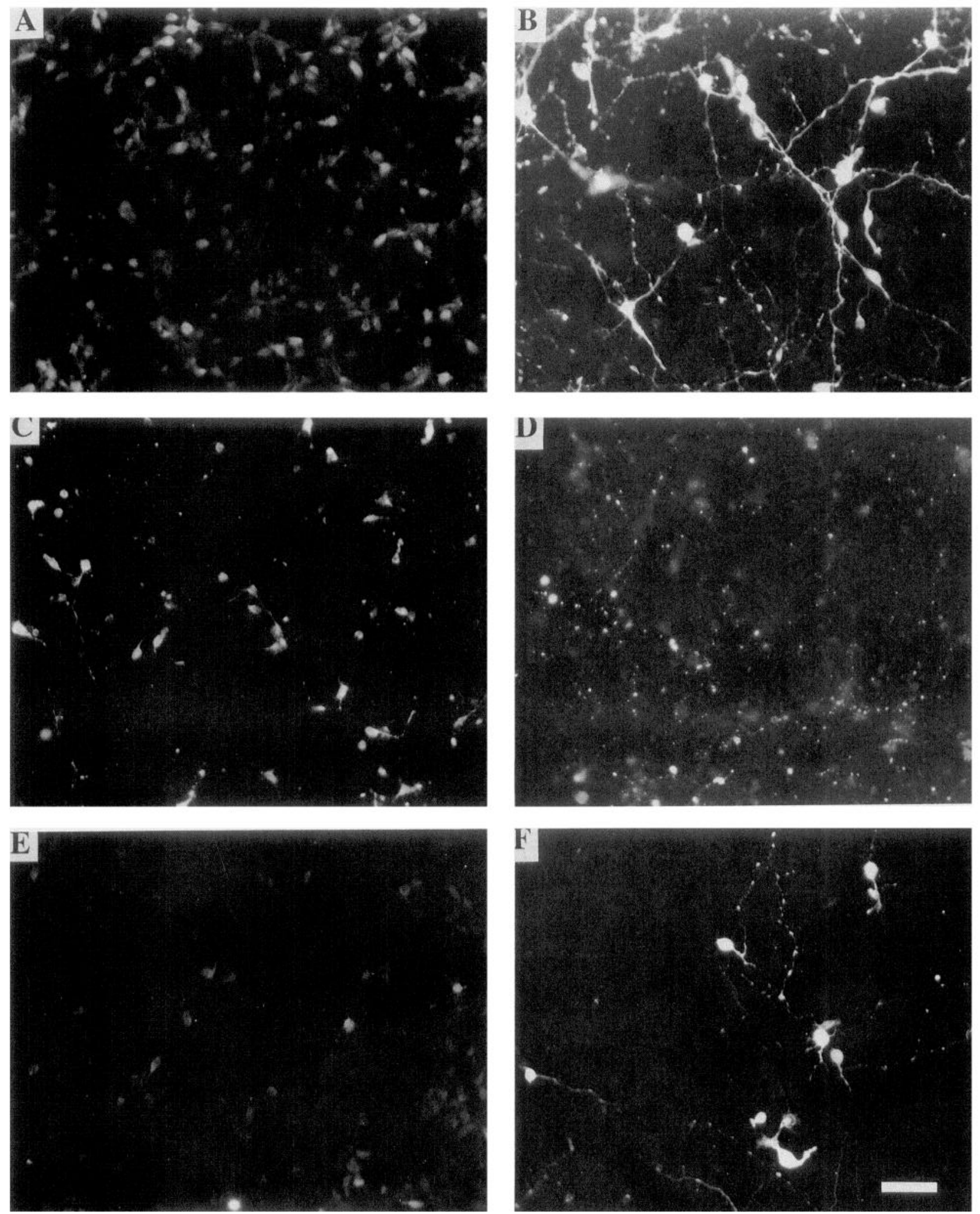

Figure 1. Illustrations of primary cultures of rat E14 ventral, mesencephalic cells in a serum-free growth medium at $16 \mathrm{hr}(A, C, E)$ and at DIV7 $(B, D, F)$. The fields illustrated are from slides that were immunostained under the same conditions, to visualize neuron-specific enolase $(A, B)$, tyrosine hydroxylase $(C, D)$, and GABA $(E, F)$. Note that at DIV7, the survival of $\mathrm{TH}^{+}$neurons in the serum-free culture was effectively $0 \%(D)$, but that many GABAergic neurons $(F)$, and other neurons $(B)$ were still present. Therefore, by DIV7, there was a specific depletion of $\mathrm{TH}^{+}$neurons in the serum-free culture. Scale bar, $20 \mu \mathrm{m}$. 

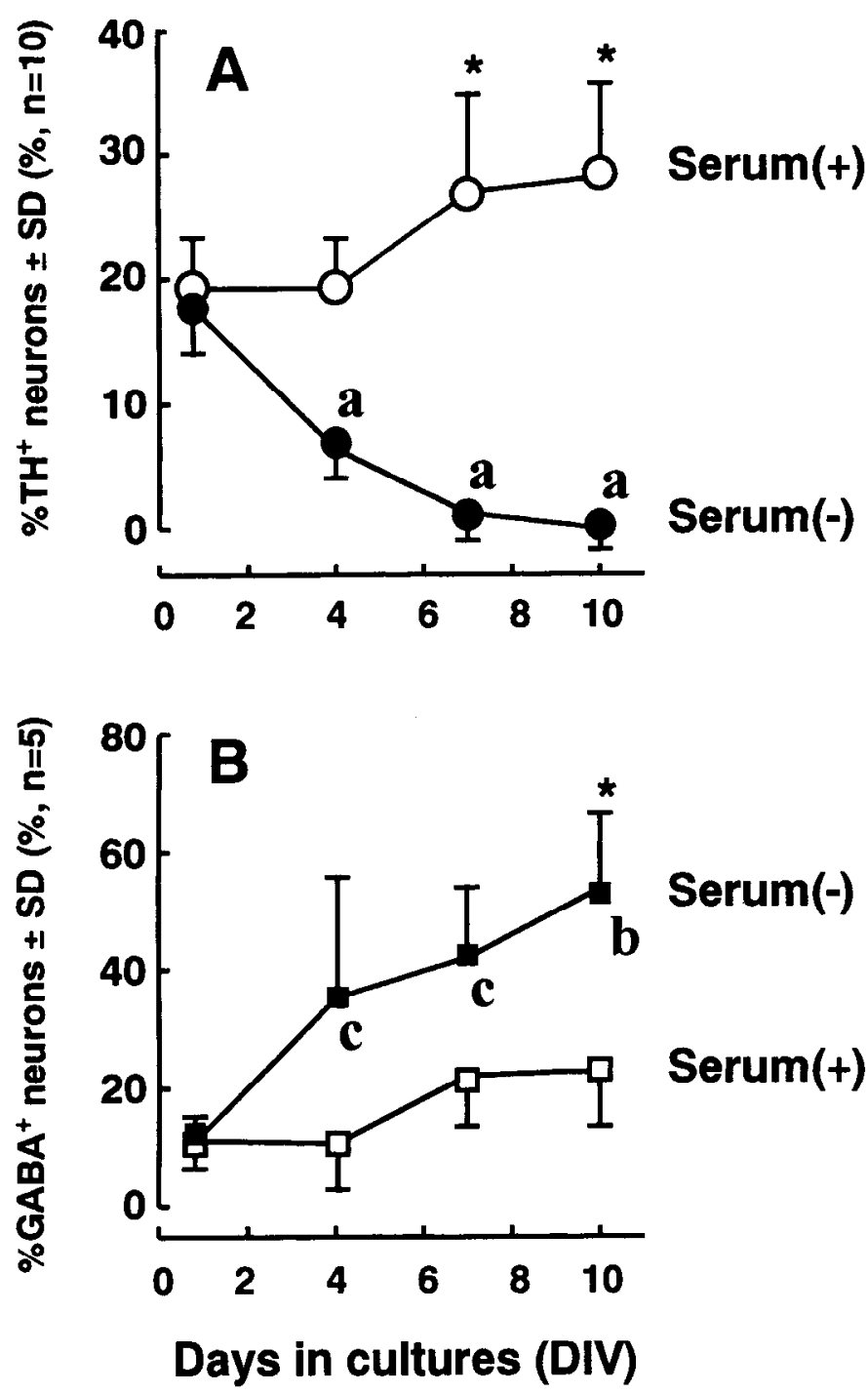

Figure 2. Differing survival of $\mathrm{TH}^{+}$and GABAergic neurons in a primary culture in serum-free $(-)$ and serum-supplemented $(+)$ growth media: $A$, At $16 \mathrm{hr}$ after plating, there was no significant difference in the percentage of $\mathrm{TH}^{+}$neurons grown in the $\operatorname{serum}(-)$ and $\operatorname{serum}(+)$ growth media. Thereafter, the percentage of $\mathrm{TH}^{+}$neurons decreased and increased in serum $(-)$ and serum $(+)$ growth media, respectively $(p$ $<0.001$, ANOVA). $B$, The percentage of GABA-IR neurons increased significantly in the serum $(-)$ medium $(p<0.01$, ANOVA), and remained unchanged in the serum $(+)$ medium. The death of $\mathrm{TH}^{+}$neurons was selectively enhanced in the serum $(-)$ medium. ${ }^{*}, p<0.05$ versus the percentage of $\mathrm{TH}^{+}$or $\mathrm{GABA}^{+}$neurons present at $16 \mathrm{hr}$ after plating. $a-c, p<0.001, p<0.01, p<0.05$, respectively, versus serum $(+)$ culture of the same age.

GFAP, but all continued to express vimentin. The effect of a mesencephalic type 1 astrocyte monolayer, on the survival of mesencephalic $\mathrm{TH}^{+}$neurons in a serum-free growth medium, with and without a mitotic inhibitor (AraC, $1.0 \mu \mathrm{M}$ ), is illustrated at DIV5 and DIV10 (Fig. 5). It was also demonstrated that microglia, which are another possible source of dopaminergic neurotrophic factors, were not present in the cultures (see Fig. $8 B$ ). However, since it was still possible that factors other than neurotrophic substances secreted by type 1 astrocytes, for example, extracellular matrix components, might contribute to the survival of $\mathrm{TH}^{+}$neurons, we tested the effect of an astrocyte monolayer previously fixed with $4 \%$ paraformaldehyde. The results (Fig. 5) illustrate that fixed astrocytes exerted a significant $(p<0.05)$ effect on the survival of $\mathrm{TH}^{+}$neurons. Type 1 astrocytes prepared from the ventral mesencephalon exerted a significantly $(p<0.01)$ greater effect on the survival of $\mathrm{TH}^{+}$ neurons, versus type 1 astrocytes prepared from the striatum or cerebral cortex (Fig. 6). This experiment was done in the presence of a mitotic inhibitor (AraC, $1.0 \mu \mathrm{M})$, to suppress the proliferation of the virgin glia $(\approx 2.5 \%)$ that are present in the plated cells.

Conditioned medium derived from mesencephalic type 1 astrocytes grown in serum-free medium had the same qualitative effect as the mesencephalic, astrocyte monolayer (Fig. 7). A dose-dependent relationship between the percentage of conditioned medium added to the culture and the percentage survival of $\mathrm{TH}^{+}$neurons was obtained. The peak effect occurred with $50 \%$ replacement. The experiment was done in the presence of $1.0 \mu \mathrm{M} \mathrm{AraC}$, to suppress the proliferation of the small $(\approx 2.5 \%)$ percentage of virgin glia normally present in the culture. Heating the conditioned medium $\left(100^{\circ} \mathrm{C}\right.$ for $\left.10 \mathrm{~min}\right)$ abolished its trophic effect. The order of potency of conditioned media derived from type 1 astrocytes from the mesencephalon, striatum, and cerebral cortex was similar to that obtained for their respective glial monolayers (Figs. 6, 7). Microglia were not detected in the confluent, astrocyte monolayer (Fig. $8 \mathrm{~B}$ ). It is therefore unlikely that a microglia-derived neurotrophic factor contributed to the observed, increased survival of $\mathrm{TH}^{+}$neurons.

\section{Discussion}

The serum-free, microisland culture as an in vitro model and a bioassay system

Primary dopaminergic neuronal cultures have been developed in many laboratories, in part, because of their potential importance in providing insights into the etiology of Parkinson's disease. These cultures are heterogeneous, consisting of several neuronal phenotypes and varying percentages of glia and glioblasts. In a previous publication (Shimoda et al., 1992), we described a primary neuronal culture with a much higher $(20 \%)$ percentage of $\mathrm{TH}^{+}$neurons, compared with values of $0.1-2.0 \%$, usually reported for similar cultures. We also demonstrated a good correlation between the percentage of $\mathrm{TH}^{+}$neurons in the culture, the uptake of dopamine by a benztropine-sensitive uptake system, and the subsequent depolarization-induced release of dopamine. In the search for putative, dopaminergic, neurotrophic factors, the correct use of a serum-free growth medium is of critical importance. If the cultures are exposed initially to serum-supplemented medium for as little as 1 or $2 \mathrm{~d}$, before switching to serum-free medium, astrocyte proliferation is stimulated, and utmost care is then required in the interpretation of the results. We have succeeded in establishing a serum-free culture that is effectively devoid of astrocytes. Therefore, the effects of serum and astrocytes could be tested independently, with negligible cross-contamination. A possible confounding factor is the $2.5 \%$ glioblasts present in the culture at plating (see Materials and Methods). The fate and possible contribution of these cells to the results reported are unknown. Some advantages of the culture used in this study are the following. (1) A high percentage $(20 \%)$ of $\mathrm{TH}^{+}$neurons were present at plating. (2) Initial priming with a serum-supplemented medium was avoided completely, thereby preventing contamination with unknown factors from serum, and suppressing glial proliferation. (3) Dopaminergic neurons survive very poorly in a serum-free medium. At $4 \mathrm{hr}$, DIV 5 and DIV 10, the percentage of $\mathrm{TH}^{+}$neurons present 

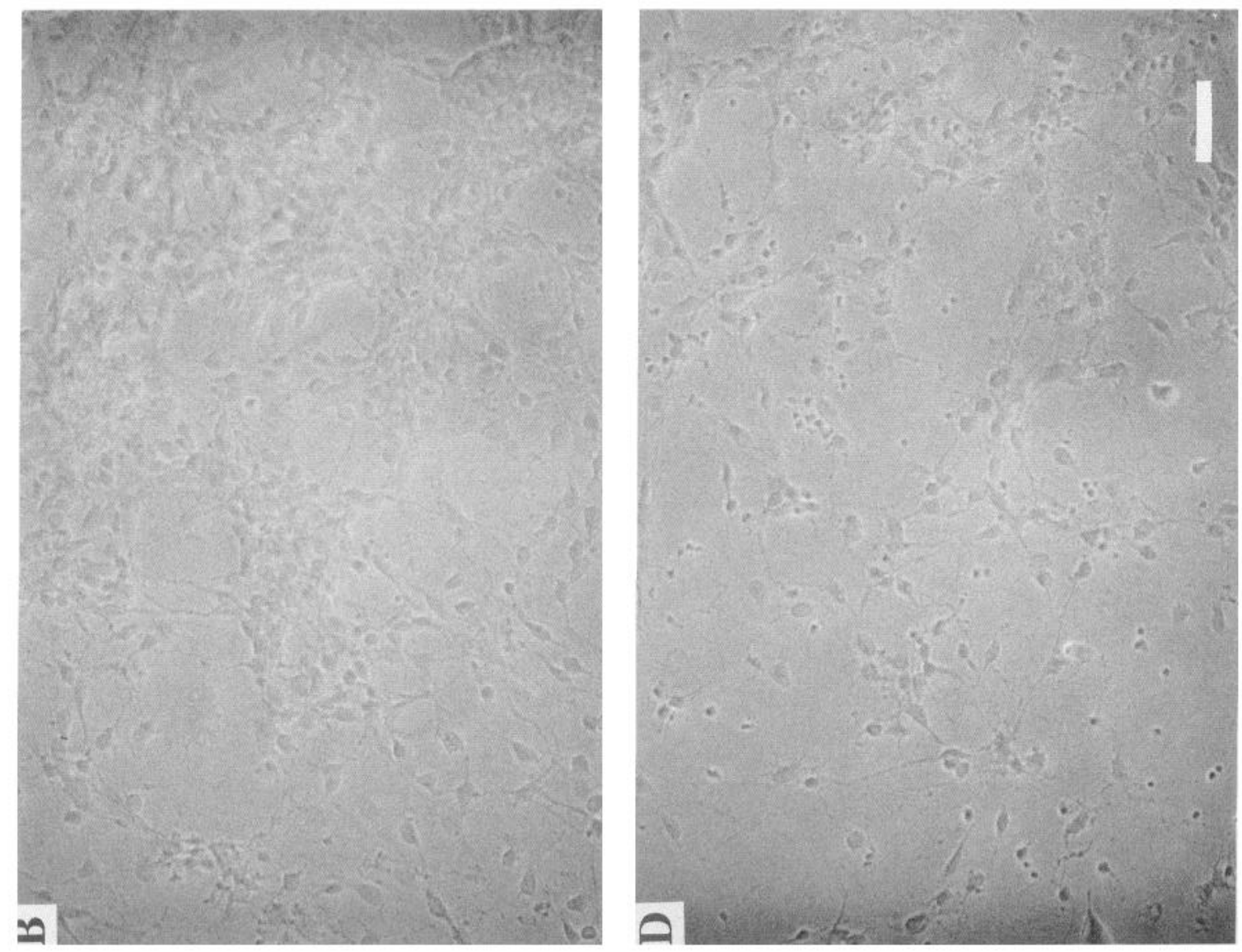

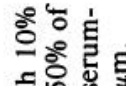
象

छ

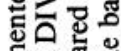

两药

를.

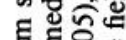

䓀这

政

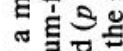

․ㅡㄹ

들⿺

品

死

ถี

$\checkmark$ 约

ज政

‡苛密

ㅇㅇㅇㅎㅁ

유웛

究

的

\& $\Xi$

ํㅡ늘

区欠

ङ웛휴

i
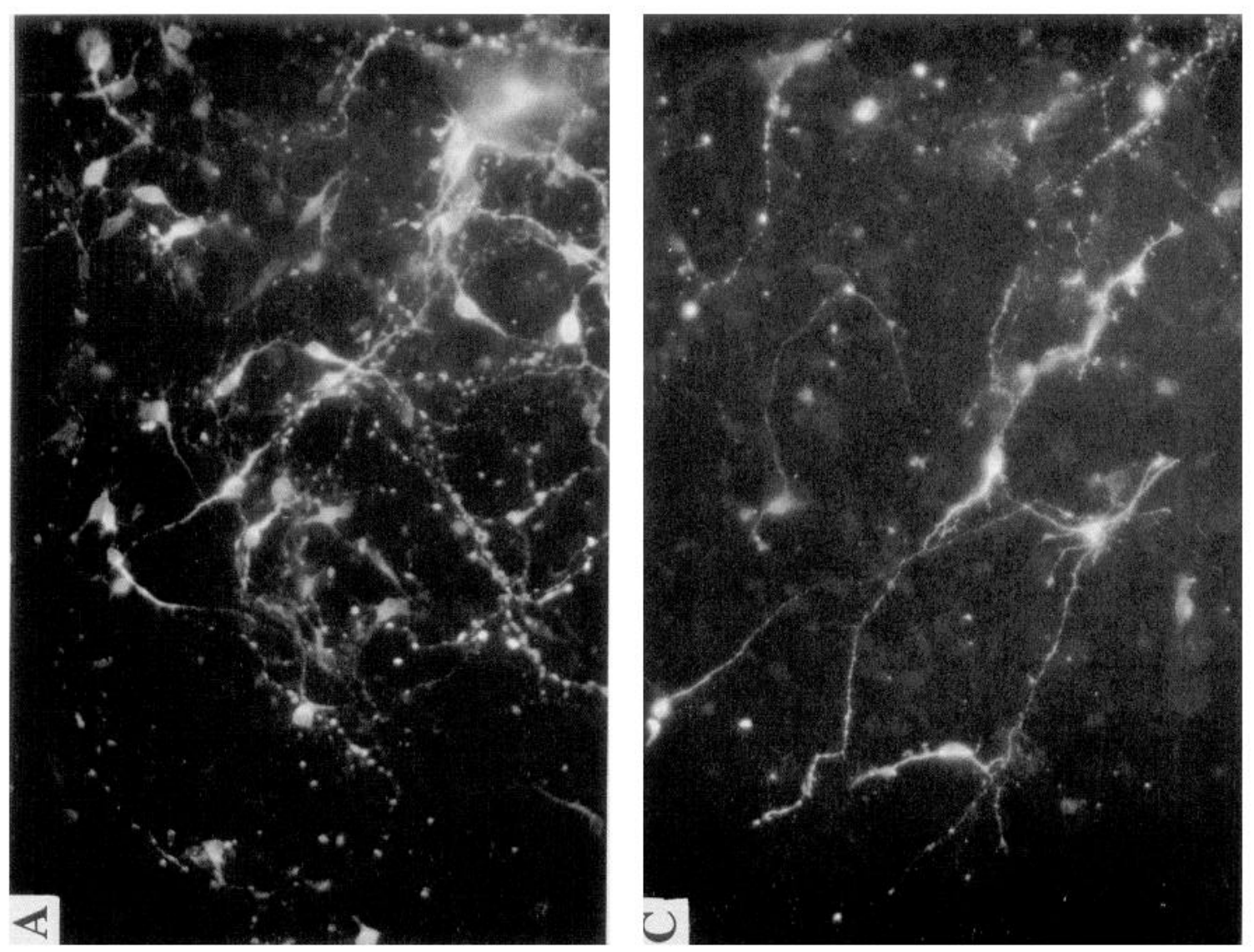

茟范

है

एँ

들

额.

है

응

o

5 a

을

녈

ह.

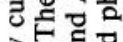

듀을

ㅅ․

皆歏

틀

ㄷㅇㅇ 웡

ก 틀

记

는

ते

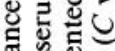

知

๘.

월을

을

诞出

ระ.․․

entin 


\begin{tabular}{|c|c|c|c|c|c|c|c|}
\hline & \multicolumn{2}{|c|}{ Vimentin } & \multicolumn{2}{|c|}{ GFAP } & \multicolumn{2}{|c|}{ A2B5 } & \multirow[b]{2}{*}{$\% \mathrm{TH} \pm \mathrm{SD}$} \\
\hline & Flat & Stellate & Flat & Stellate & Flat & Stellate & \\
\hline \multicolumn{8}{|l|}{ DIV 4} \\
\hline 0.0 & \pm & ++ & - & - & - & + & $5.6 \pm 4.6$ \\
\hline 2.5 & + & ++ & - & \pm & - & \pm & $11.3 \pm 1.8$ \\
\hline 5.0 & + & + & \pm & + & - & \pm & $10.9 \pm 3.5$ \\
\hline 10.0 & ++ & + & + & + & - & \pm & $15.5 \pm 4.3$ \\
\hline 15.0 & ++ & + & + & + & - & \pm & $17.0 \pm 3.2$ \\
\hline \multicolumn{8}{|c|}{ DIV 10} \\
\hline 0.0 & + & + & - & - & - & + & $0.5 \pm 0.7$ \\
\hline 2.5 & ++ & + & ++ & + & - & \pm & $6.3 \pm 1.3$ \\
\hline 5.0 & +++ & + & +++ & $+t$ & - & \pm & $5.6 \pm 1.3$ \\
\hline 10.0 & +++ & \pm & +++ & \pm & - & \pm & $26.2 \pm 6.7$ \\
\hline 15.0 & +++ & \pm & +++ & \pm & - & - & $30.1 \pm 8.4$ \\
\hline
\end{tabular}

- , None;,$\pm<1 /$ field;,$+ 1-10 /$ field;,$++ 11-100 /$ held;,$+++ 101 /$ field: confluent. Changes of $\% \mathrm{TH}^{+}$, neurons at DIV 4 and 10 were statistically significant: $p<0.001$ (ANOVA). A $20 \times$ objective lens was used throughout. The area of the field photographed is $0.38 \mathrm{~mm}^{2}$.

in the culture was $20 \%, 2.5 \%$, and $<1 \%$, respectively. This finding provided an ideal experimental condition in which to test the effectiveness of various factors to reduce the death of $\mathrm{TII}^{+}$ neurons. (4) The expression of GFAP occurred after DIV10. A limiting factor with the method used is that relatively fewer cells per fetus are obtained, in comparison with the use of less-refined

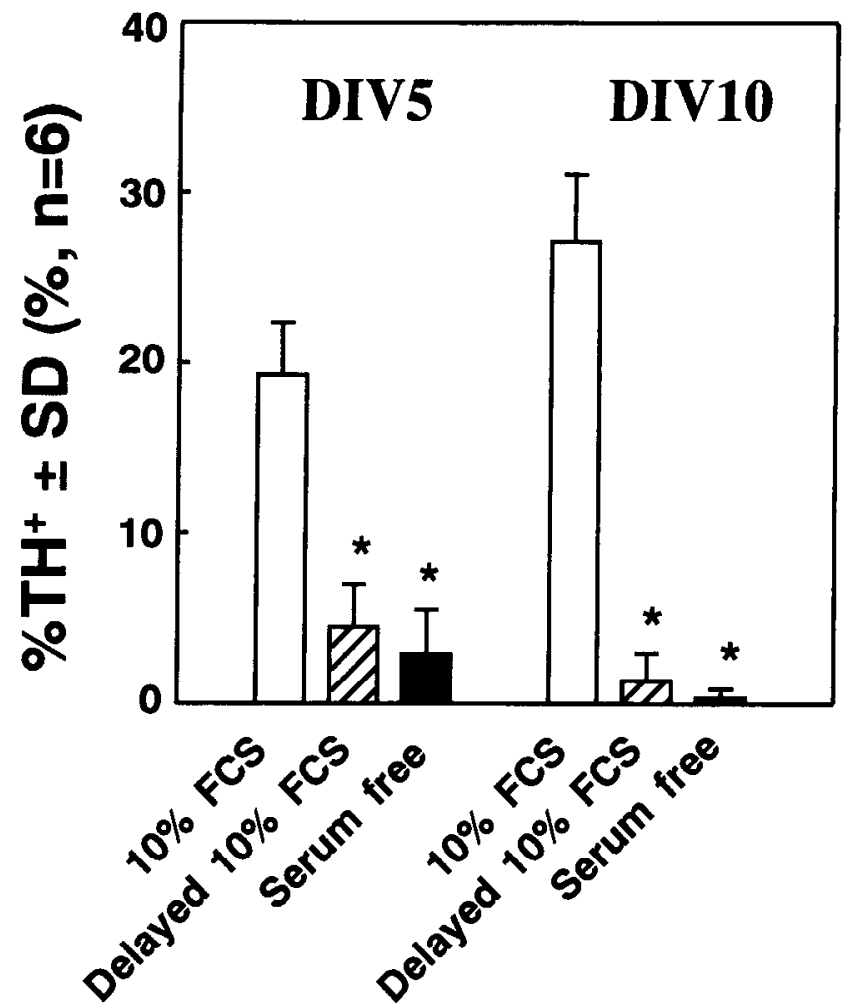

Figure 4. The effect of delayed addition of $10 \%$ serum to cultures that were initially serum free, and grown in the presence of $1.0 \mu \mathrm{M} \mathrm{AraC}$. The serum was added $48 \mathrm{hr}$ after plating, and the percentage of $\mathrm{TH}^{+}$ neurons in the cultures was increased significantly at both DIV 5 and DIV10 ( $p<0.001$, ANOVA), versus the cultures that remained serumfree. ${ }^{*}, p<0.05$ versus culture supplemented with $10 \%$ serum (post hoc testing). dissection techniques. We compensated for this limitation in two ways. First, we employed methods during the dissection and storage of the tissue that preserved the viability of the cells. Viability was always $>90 \%$ at plating. Second, we used a microisland culturing technique, in which $1.25 \times 10^{4}$ cells were plated on a $6.2 \mathrm{~mm}^{2}$ area, at a final density of $2.0 \times 10^{5} / \mathrm{cm}^{2}$. We also verified (Shimoda et al., 1992) that dopamine is taken up by a benztropine-sensitive mechanism, stored, and subsequently released by a depolarization-dependent process. Some

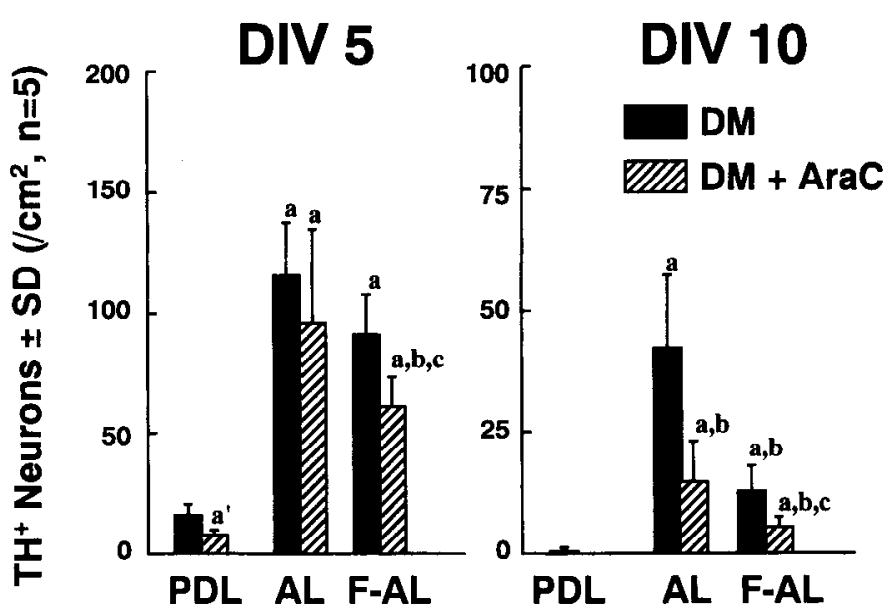

Figure 5. The effect of a ventral mesencephalic, astrocyte monolayer on the survival of $\mathrm{TH}^{+}$neurons in a primary culture. The cells were platcd cither on a substrate of poly-D-lysine $(P D L)$, or a viable astrocyle monolayer $(A L)$, or an astrocyte monolayer previously fixed (see Materials and Methods) with $4 \%$ paraformaldehyde $(F-A L)$, and cultured in a defined medium $(D M)$, or in a defined medium containing the mitotic inhibitor $(1.0 \mu \mathrm{M})$ cytosine arabino furanoside $(D M+A r a C)$. The results show that the viable astrocyte monolayer was highly effective in protecting dopaminergic neurons from death, but also that the fixed astrocyte monolayer had a significant protective effect. The $\mathrm{TH}^{+}$neurons were estimated at DIV5 and DIV10. $p<0.001$ (ANOVA) at DIV5 and DIV10. $a, p<0.05$ versus PDL without and with AraC; $a^{\prime}, p<$ 0.05 versus PDL without AraC; $b, p<0.05$ versus AL without AraC; $c, p<0.05$ versus $\mathrm{AL}$ with $\mathrm{AraC}$ and F-AL without AraC (post hoc multiple comparison test). 


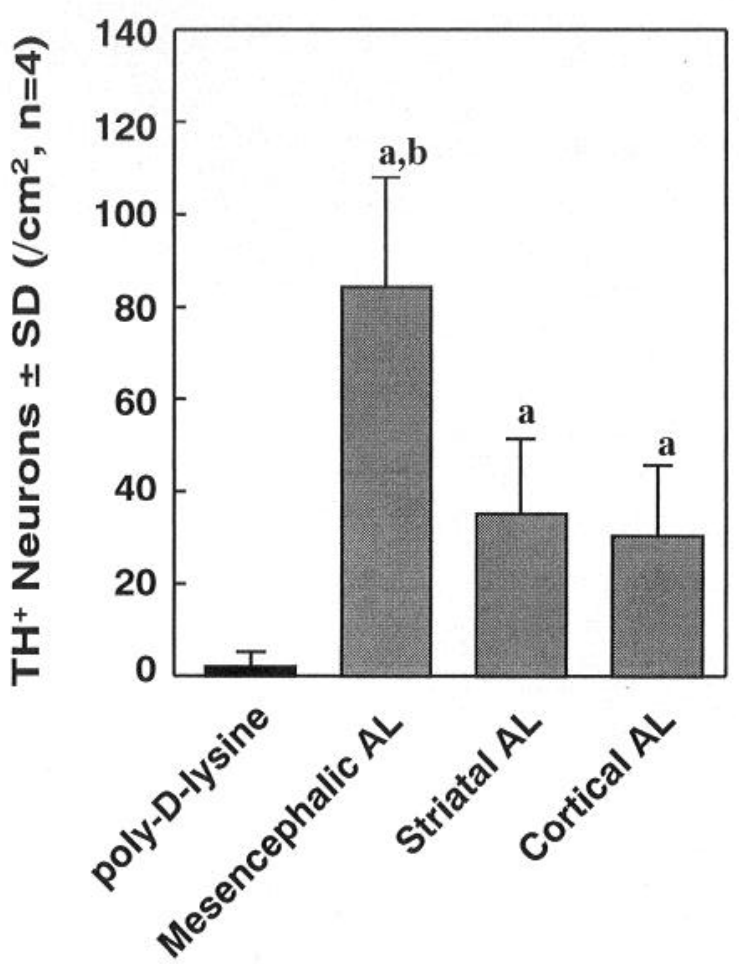

Figure 6. Differences in the effectiveness of astrocyte monolayers prepared from the ventral mesencephalon, striatum, and cerebral cortex of the E16 rat, in protecting $\mathrm{TH}^{+}$neurons from death in a primary culture. The cells were plated at the same density $\left(2.0 \times 10^{5} / \mathrm{cm}^{2}\right)$, grown in a defined medium containing the mitotic inhibitor $\operatorname{AraC}(1.0 \mu \mathrm{M})$, and the number of $\mathrm{TH}^{+}$neurons was estimated at DIV5. The mesencephalic astrocytes provided the highest protective effect. The striatal and cortical astrocytes were of equal potency. $p<0.001$ ANOVA. $a, p<0.05$ versus controls (poly-D-lysine-coated glass). $b, p<0.05$ versus striatum and cortex (post hoc test).

types of glia also take up and release dopamine and GABA (Semenoff and Kimelberg, 1985; Allen et al., 1986; Kimelberg and Katz, 1986; Larsson et al., 1986; Reynolds and Herschkowitz, 1986; Magoski et al., 1992). However, most of the dopamine that is taken up by glia is metabolized.

It is possible that the marked reduction in the percentage of $\mathrm{TH}^{+}$neurons in the serum-deprived culture (Fig. $1 D$ ) was caused by a suppression of the expression of $\mathrm{TH}$. We tested this hypothesis by supplementing the cultures with $10 \%$ FCS at $48 \mathrm{hr}$ after plating (Fig. 4). Normally, in serum-free cultures, the percentage of $\mathrm{TH}^{+}$neurons is significantly reduced $(p<0.01)$ from $20 \%$ at plating to $<10 \%$ by DIV 3 , and $<1 \%$ by DIV 10 . We reasoned that if serum deprivation inhibited the expression of $\mathrm{TH}$ without causing the death of dopaminergic neurons, then serum supplementation should reverse the inhibition. At DIV5 and DIV10, after serum supplementation at DIV2, the percentage of $\mathrm{TH}^{+}$neurons was not significantly different from the nonsupplemented controls (Fig. 4). This result suggests, but does not prove, that serum deprivation is toxic to $\mathrm{TH}^{+}$neurons in culture. In serum-free versus serum-supplemented cultures, at DIV7, the percentage of $\mathrm{TH}^{+}$neurons was decreased by $25 \%$, while the percentage of GABA-IR neurons was increased by $25 \%$. This exact reciprocal relationship between $\mathrm{TH}^{+}$and $\mathrm{GABA}-$ IR neurons strengthens the suggestion that serum deprivation may have a selective, toxic effect on $\mathrm{TH}^{+}$neurons, but not on GABA-IR neurons.

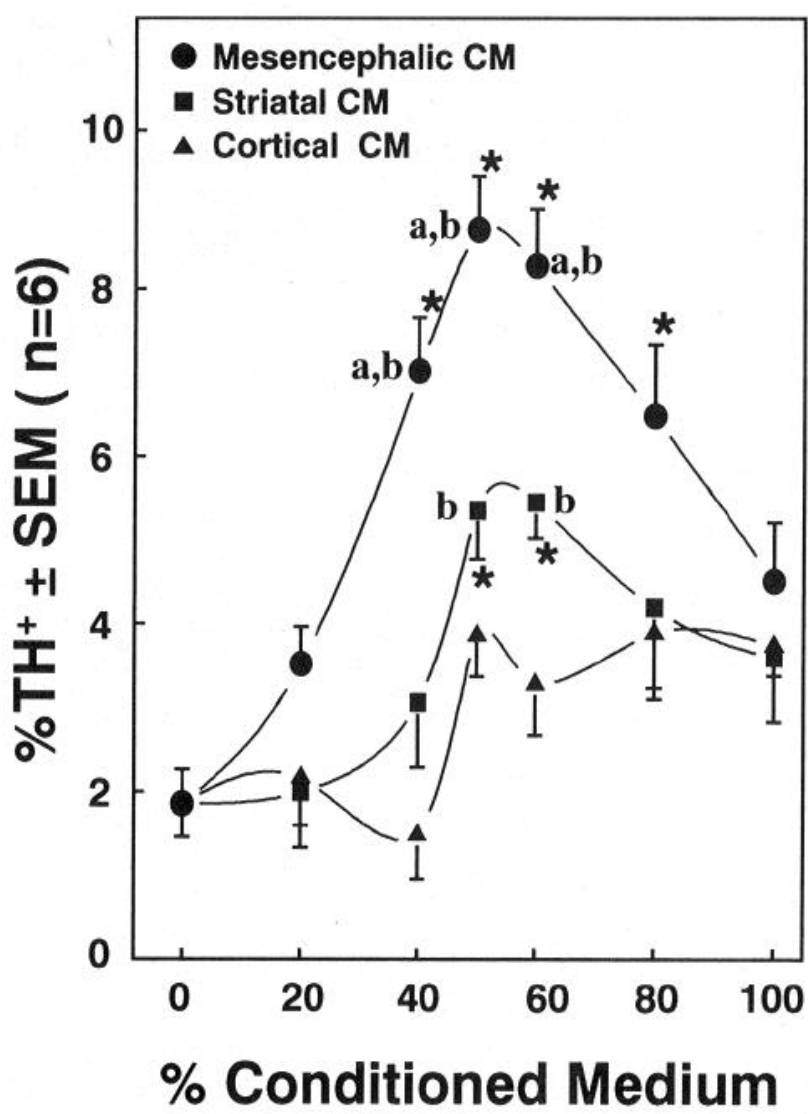

Figure 7. Dose-dependent effect of conditioned media prepared from confluent, type 1 astrocytes from the ventral mesencephalon $(\bullet)$, striatum (), and cerebral cortex $(\mathbf{\Delta})$ of the El6 rat, in protecting $\mathrm{TH}^{+}$ neurons from death. The protein concentrations of the CM were 54.2, 55.6 (diluted $1.03 \times$ ), and 56.4 (diluted $1.04 \times) \mu \mathrm{g} / \mathrm{ml}$ for the mesencephalic, striatal, and cortical cultures, respectively. The rank order of potency was ventral mesencephalon $>$ striatum $>$ cerebral cortex. The percentage of $\mathrm{TH}^{+}$neurons in the culture was estimated at DIV5. The protective effect of the CM peaked at about $50-60 \%$ replacement, and then declined. Mesencephalic CM $(F=18.0), p<0.001$ (ANOVA). Striatal CM $(F=5.96), p<0.05$ (ANOVA). Cortical CM $(F=3.42)$, not significant. $a, p<0.05$ versus striatal $\mathrm{CM}$ of the same percentage. $b, p<0.05$ versus cortical CM of the same percentage. Student-NeumanKeuls post hoc test was used.

\section{Serum versus astrocytes}

Although glia proliferation has been reported to be suppressed in serum-free cultures (Prochiantz et al., 1979; Ahmed et al., 1983; O'Malley et al., 1991), the problem has not been studied in depth. We therefore made a detailed comparison of the neurotrophic effect of serum versus astrocytes, both of which are known to exert neurotrophic effects in primary neuronal cultures. A comparison of the dose-dependent effect of serum on the survival of $\mathrm{TH}^{+}$, and the proliferation of glia, including astrocytes (Table 2), appears to suggest that enhanced neuronal survival is mediated by the proliferation of astrocytes. However, at DIV4, in cultures supplemented with $15 \%$ serum, glia are not yet confluent, yet neuronal survival is enhanced. Similarly, in cultures supplemented with $10 \%$ serum, and grown in the presence of the mitotic inhibitor $\operatorname{AraC}(1.0 \mu \mathrm{M})$ death of $\mathrm{TH}^{+}$neurons in the culture did not occur until after DIV9. This constitutes the serum-mediated, astrocyte-independent phase of the survival of dopaminergic neurons in a primary culture (Take- 

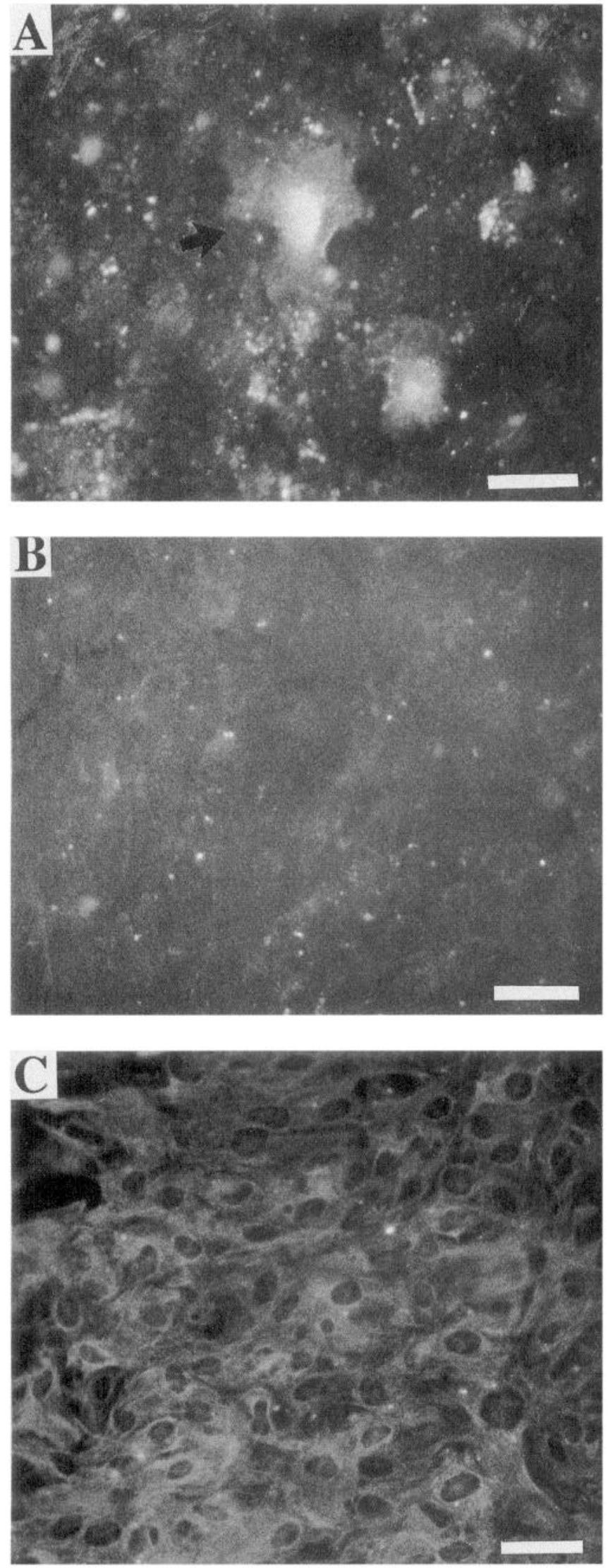

Figure 8. Lack of contamination of confluent, astrocyte monolayer with microglia. $A$, Microglia stained with anti-OX-42 at DIV10, in a mixed culture, prepared from the E16 rat cerebral cortex, and grown in shima et al., 1994). Therefore, serum has a direct effect on the survival of $\mathrm{TH}^{+}$neurons in culture, and an indirect effect that is mediated by factors produced by confluent astrocytes. Thus, when grown in a serum-supplemented medium, with a mitotic inhibitor (AraC, $1.0 \mu \mathrm{M}$ ), the increased death of $\mathrm{TH}^{+}$neurons after DIV9 is due mainly to inhibition of the proliferation of astrocytes.

\section{Role of astrocytes}

The selective, accelerated death of dopaminergic neurons, induced by serum deprivation, is a new finding. In previous studies in which a serum-free growth medium was used, the presence of GFAP-positive astrocytes was an important, confounding factor (O'Malley et al., 1991). In the present experiments, care was taken to exclude GFAP-positive cells when the effect of serum deprivation was being studied. Under these conditions, the enhanced death of dopaminergic neurons is very evident. The generalized neurotrophic effect of confluent astrocytes has been demonstrated repeatedly, and is the basis of their use as nonspecific feeder layers in primary neuronal cultures. However, the exact mechanism of the neurotrophic effect of type 1 astrocytes is not understood. The positive effect of the astrocyte feeder layer was reduced, but present, even after fixation of the feeder layer with paraformaldehyde. Two apparently distinct mechanisms may therefore account for the neurotrophic effect of the astrocyte feeder layer on the survival of dopaminergic neurons in culture: (1) physical support of neurons afforded by enlargement of the surface area for attachment of the neurons, a roughened surface, the presence of components of the extracellular matrix that are not denatured by fixation, and possibly active compounds extruded during permeabilization during the fixation procedure; (2) synthesis and secretion of neurotrophic factors that maintain neuronal survival. Microglia were not found in the confluent, astrocyte cultures tested. It is therefore unlikely that microglia contributed to the neurotrophic action of type 1 astrocyte culture observed in this study.

\section{Local versus target support of neuronal survival}

Target-derived neurotrophic support for neurons in the PNS is well established. Similar mechanisms are thought to be present in the CNS. The striatum is the major target for dopaminergic neurons originating in the zona compacta of the substantia nigra, and some apparently successful attempts have been made to identify the striatal-derived neurotrophic factors that are specific for dopaminergic neurons (Prochiantz et al., 1979, 1981; Di Porzio et al., 1980; Denis-Donini et al., 1983, 1984). During ontogeny, before the growing axons arrive at their targets, local, glial-mediated neurotrophic support is probably important for survival of dopaminergic neurons (O'Malley et al., 1991, 1992). We found a robust, protective effect of astrocytes derived from the ventral mesencephalon, on mesencephalic dopaminergic neurons in culture (Fig. 6). Astrocytes derived from the striatum and frontal cerebral cortex exerted significantly $(p<0.05)$ weaker, protective effects, compared with mesencephalic astrocytes.

a medium with $10 \%$ fetal calf serum. $B$, The confluent monolayer of type 1 astrocytes stained negative with anti-OX-42. $C$, Illustration of the confluent monolayer of type 1 astrocytes, stained with anti-GFAP, at DIV16, or the fifth day after last change of serum-free medium. Scale bars, $20 \mu \mathrm{m}$. 


\section{Glial phenotypes as sources of dopaminergic neurotrophic factors}

In addition to type 1 astrocytes, microglia (Akiyama and McGeer, 1989; Vaca and Wendt, 1992; Nagata et al., 1993) and cytokines (Hama et al., 1991; Kushima et al., 1992) have also been reported to exert neurotrophic cffccts on dopamincrgic neurons in a primary culture. Type 2 astrocytes and oligodendrocytes are thought not to exert any significant, neurotrophic effect on dopaminergic neurons (O'Malley et al., 1992). We have observed a poor survival of mesencephalic dopaminergic neurons when grown on a layer of mixed oligodendrocyte and type 1 astrocytes (unpublished observation). However, we have also observed that the progenitor cell for oligodendrocytes and type 2 astrocytes (O-2A progenitor) exerts an unusually strong, neurotrophic effect on dopaminergic neurons (Takeshima et al., unpublished observation). Thus, type 1 astrocytes, microglia, and $\mathrm{O}-2 \mathrm{~A}$ progenitors all exert positive neurotrophic effects on the survival of dopaminergic neurons in a primary culture. $\mathrm{Fu}$ ture research will determine whether a common mechanism of action is shared by the three types of glia, or whether each produces unique neurotrophic factors.

\section{Conclusions}

(1) We have developed a method to dissect the A8, A9, and A 10 dopaminergic nuclei $\left(\approx 1.0 \mathrm{~mm}^{3}\right.$ block of tissue) of the ventral mesencephalon of the E14 rat. At $4 \mathrm{hr}$ after plating, 95\% of the cells are neurons (NSE positive), 20\% are dopaminergic $\left(\mathrm{TH}^{+}\right)$, and $<5 \%$ are glioblasts (vimentin positive). When cultured in a serum-free medium, no cells expressed GFAP throughout the observation period ( $4 \mathrm{hr}$ to $10 \mathrm{~d}$ ). The preparative procedure we have described, if done as suggested, should provide an excellent bioassay system, in combination with biochcmical and molecular methods, to be used in the isolation of novel, dopaminergic neurotrophic factors. (2) Serum deprivation caused the selective death of dopaminergic neurons in a primary culture. GABAergic neurons were not significantly affected. (3) Confluent, mesencephalic type 1 astrocytes (95\% pure) and the conditioned medium prepared from them rescued dopaminergic neurons from death induced by serum deprivation. (4) A major cause of death of dopaminergic neurons in serumfree growth medium may be related to the suppression of proliferation of type 1 astrocytes.

\section{References}

Ahmed Z, Walker PS, Fellows RE (1983) Properties of neurons from dissociated fetal rat brain in serum-free culture. J Neurosci 3:24482462.

Akiyama H, McGeer PL (1989) Microglial response to 6-hydroxydopamine-induced substantia nigra lesions. Brain Res 489:247-253.

Alderson RF, Alterman AL, Barde Y-A, Lindsay RM (1990) Brainderived neurotrophic factor increases survival and differentiated functions of rat septal cholinergic neurons in culture. Neuron 5:297-306.

Allen IC, Schousboe A, Griffiths R (1986) Effect of L-homocysteine and derivatives on the high-affinity uptake of taurine and GABA into synaptosomes and cultured neurons and astrocytes. Neurochem Res $11: 1487-1496$.

Appel SH (1981) A unifying hypothesis for the cause of amyotrophic latcral sclerosis, parkinsonism, and Alzheimer disease. Ann Neurol 10:499-505.

Barde YA (1989) Trophic factors and neuronal survival. Neuron 2:1525-1534.

Basilico C, Moscatelli D (1992) The FGF family of growth factors and oncogenes. Adv Cancer Res 59:115-165.

Besnard F, Perraud F, Sensenbrenner M, Labourdette G (1987) Plate- let-derived growth factor is a mitogen for glial but not for neuronal rat brain cells in vitro. Neurosci Lett 73:287-292.

Casper D, Mytilineou C, Blum M (1991) EGF enhances the survival of dopamine neurons in rat embryonic mesencephalon primary cell culture. J Neurosci Res 30:372-381.

Denis-Donini S, Glowinski J, Prochiantz A (1983) Specific influence of striatal target neurons on the in vitro outgrowth of mesencephalic dopaminergic neurites: a morphological quantitative study. J Neurosci 3:2292-2299.

Denis-Donini S, Glowinski J, Prochiantz A (1984) Glial heterogeneity may define the three-dimensional shape of mouse mesencephalic dopaminergic neurones. Nature 307:641-643.

Diamond SG, Markham CH, Hoehn MM, McDowell FH, Muenter MD (1989) Effect of age at onset on progression and mortality in Parkinson's disease. Neurology 39:1187-1190.

Di Porzio U, Daguet M-C, Glowinski J, Prochiantz A (1980) Effect of striatal cells on in vitro maturation of mesencephalic dopaminergic neurons grown in serum-free conditions. Nature 288:370-373.

Engele J, Bohn MC (1991) The neurotrophic effects of fibroblast growth factors on dopaminergic neurons in vitro are mediated by mesencephalic glia. J Neurosci 11:3070-3078.

Engele J, Schubert D, Bohn MC (1991) Conditioned media derived from glial cell lines promote survival and differentiation of dopaminergic neurons in vitro: role of mesencephalic glia. I Neurosci Res 30:359-371.

Ferrari G, Minozzi MC, Toffano G, Leon A, Skaper SD (1989) Basic fibroblast growth factor promotes the survival and development of mesencephalic neurons in culture. Dev Biol 133:140-147.

Ferrari G, Toffano G, Skaper SD (1991) Epidermal growth factor exerts neuronotrophic effects on dopaminergic and GABAergic CNS neurons: comparison with basic fibroblast growth factor. J Neurosci Res 30:493-497.

Hadjiconstantinou M, Fitkin JG, Dalia A, Neff NH (1991) Epidermal growth factor enhances striatal dopaminergic parameters in the 1-methyl-4-phenyl-1,2,3,6-tetrahydropyridine-treated mouse. J Neurochem 57:479-482.

Hama T, Kushima Y, Miyamoto M, Kubota M, Takei N, Hatanaka $H$ (1991) Interleukin-6 improves the survival of mesencephalic catecholaminergic and septal cholinergic neurons from postnatal, twoweek-old rats in cultures. Neuroscience 40:445-452.

Hefti F, Michel PP, Knüsel B (1990) Neurotrophic factors and Parkinson's disease. Adv Neurol 53:123-127.

Hyman C, Hofer M, Barde Y-A, Juhasz M, Yancopoulos GD, Squinto SP, Lindsay RM (1991) BDNF is a neurotrophic factor for dopaminergic neurons of the substantia nigra. Nature 350:230-232.

Kimelberg HK, Katz DM (1986) Regional differences in 5-hydroxytryptamine and catecholamine uptake in primary astrocyte cultures. J Neurochem 47:1647-1652.

Knüsel B, Winslow JW, Rosenthal A, Burton LE, Seid DP, Nikolics K, Hefti $F$ (1991) Promotion of central cholinergic and dopaminergic neuron differentiation by brain-derived neurotrophic factor but not neurotrophin 3. Proc Natl Acad Sci IJSA 88:961-965.

Knüsel B, Beck KD, Winslow JW, Rosenthal A, Burton LE, Widmer HR, Nikolics K, Hefti F (1992) Brain-derived neurotrophic factor administration protects basal forebrain cholinergic but not nigral dopaminergic neurons from degenerative changes after axotomy in the adult rat brain. J Neurosci 12:4391-4402.

Kushima Y, Hama T, Hatanaka H (1992) Interleukin-6 as a neurutrophic factor for promoting the survival of cultured catecholaminergic neurons in a chemically defined medium from setal and postnatal rat midbrains. Neurosci Res 13:267-280.

Larsson OM, Hertz L, Schousboe A (1986) Uptake of GABA and nipecotic acid in astrocytes and neurons in primary cultures: changes in the sodium coupling ratio during differentiation. J Neurosci Res 16:699-708.

Lin L-FH, Doherty DH, Lile JD, Bektesh S, Collins F (1993) GDNF: a glial cell-line derived neurotrophic factor for midbrain dopaminergic neurons. Science 260:1130-1132.

Magoski NS, Walz W, Juurlink BHJ (1992) Identification of mouse type-2-like astrocytes: demonstration of glutamate and GABA transmitter activated responses. J Neurosci Res 33:91-102.

McCarthy KD, De Vellis J (1980) Preparation of separate astroglial and oligodendroglial cell cultures from rat cerebral tissue. J Cell Biol 85:890-902.

Nagata K, Takei N, Nakajima K, Saito H, Kohsaka S (1993) Microglial 
conditioned medium promotes survival and development of cultured mesencephalic neurons from embryonic rat brain. J Neurosci Res 34: 357-363.

Nikkhah G, Odin P, Smits A, Tingström A, Othberg A, Brundin P, Funa K, Lindvall O (1993) Platelet-derived growth factor promotes survival of rat and human mesencephalic dopaminergic neurons in culture. Exp Brain Res 92:516-523.

Nonomura T, Hatanaka H (1992) Neurotrophic effect of brain-derived neurotrophic factor on basal forebrain cholinergic neurons in culture from postnatal rats. Neurosci Res 14:226-233.

O'Malley EK, Black IB, Dreyfus CF (1991) Local support cells promote survival of substantia nigra dopaminergic neurons in culture. Exp Neurol 112:40-48.

O'Malley EK, Sieber BA, Black IB, Dreyfus CF (1992) Mesencephalic type I astrocytes mediate the survival of substantia nigra dopaminergic neurons in culture. Brain Res 582:65-70.

Oppenheim RW (1989) The neurotrophic theory and naturally occurring motoneuron death. Trends Neurosci 12:252-255.

Otto D, Grothe C, Westermann R, Unsicker K (1991) Basic FGF and its actions on neurons: a group account with special emphasis on the parkinsonian brain. Adv Exp Med Biol 296:239-247.

Peterson GL (1977) A simplification of the protein assay method of Lowry et al. which is more generally applicable. Anal Biochem 83: 346-356

Poltorak M, Shimoda K, Freed WJ (1990) Cell adhesion molecules (CAMs) in adrenal medulla in situ and in vitro: enhancement of chromaffin cell L1/Ng-CAM expression by NGF. Exp Neurol 1 10:52-72.

Prochiantz A, Di Porzio U, Kato A, Berger B, Glowinski J (1979) In vitro maturation of mesencephalic dopaminergic neurons from mouse embryos is enhanced in presence of their striatal target cells. Proc Natl Acad Sci USA 76:5387-5391.

Prochiantz A, Daguet M-C, Herbet A, Glowinski J (1981) Specific stimulation of in vitro maturation of mesencephalic dopaminergic neurons by striatal membranes. Nature 293:570-572.

Reynolds R, Herschkowitz N (1986) Selective uptake of neuroactive amino acids by both oligodendrocytes and astrocytes in primary dissociated culture: a possible role for oligodendrocytes in neurotransmitter metabolism. Brain Res 371:253-266.

Schachner M (1983) Immunohistochemistry and immunocytochemistry of neural cell types in vitro and in situ. In: Immunohistochemistry (Cuello AC, ed), pp 399-429. New York: Wiley.

Semenoff D, Kimelberg HK (1985) Autoradiography of high affinity uptake of catecholamines by primary astrocyte cultures. Brain Res 348:125-136.

Shimoda K, Sauvé Y, Marini A, Schwartz JP, Commissiong JW (1992) A high percentage yield of tyrosine hydroxylase-positive cells from rat E14 mesencephalic cell culture. Brain Res 586:319-331.

Spina MB, Squinto SP, Miller J, Lindsay RM, Hyman C (1992) Brainderived neurotrophic factor protects dopamine neurons against 6-hydroxydopamine and $N$-methyl-4-phenylpyridinium ion toxicity: involvement of the glutathione system. J Neurochem 59:99-106.

Takeshima T, Shigematsu K, Shimoda K, Commissiong JW (1992) Developmental aspects of the primary culture of mesencephalic dopaminergic neurons. Soc Neurosci Abstr 22:1292.

Takeshima T, Shimoda K, Sauve Y, Commissiong JW (1994) Astrocyte-dependent and -independent phases of the development and survival of rat E14 mesencephalic, dopaminergic neurons in culture. Neuroscience, in press.

Vaca K, Wendt E (1992) Divergent effects of astroglial and microglial secretions on neuron growth and survival. Exp Neurol 118:62-72.

Walsh E, Ueda Y, Nakanishi H, Yoshida K (1992) Neuronal survival and neurite extension supported by astrocyles co-cultured in transwells. Neurosci Lett 138:103-106. 